\title{
КОНФЛИКТОЛОГИЯ
}

UDC 323.25

\section{Social protests in Kazakhstan: Factors and trends}

\author{
G. O. Nasimova, M. M. Buzurtanova, N. A. Saitova \\ Al-Farabi Kazakh National University, \\ 71, al-Farabi pr., Almaty, 050040, Republic of Kazakhstan
}

For citation: Nasimova G. O., Buzurtanova M. M., Saitova N. A. Social protests in Kazakhstan: Factors and trends. Vestnik of Saint Petersburg University. Philosophy and Conflict Studies, 2019, vol. 35, issue 3, pp. 472-484. https://doi.org/10.21638/spbu17.2019.307

The authors discuss the features of protests in Kazakhstan and identify their factors and causes. The analysis of the content of the sociological surveys, the posts on the social networks, the web sides and blogs of Kazakhstan's top officials enabled the authors to establish the issues of social and economic nature that are the most probable triggers of protests. The authors conceptualize their root causes as a discrepancy between the articulated goals of modernization and poor performance of the public administration responsible for their implementation. The authors' analysis goes beyond the changes of protest behavior and includes the responses of the state organs and the role of the Internet. Further, the article provides a typology of the protests occurred in Kazakhstan and deals with their scale and scope. The article also touches upon the means employed by the state to diffuse social tensions and the respective role of civil society institutions, which is argued to be insufficient. The authors conclude that the protests in Kazakhstan are spatially and topically limited, as is their destructive potential. Kazakhstan shall not anticipate massive protest actions due to the impact of the currently implemented social and economic reforms, commitment of the majority of its citizens to maintenance of political stability and their fear of possible destructive consequences, as well as the lack of any organized political force capable of transforming public discontent into political actions and underdevelopment of civil society.

Keywords: protests, conflicts, modernization, state, government.

\section{Introduction}

Protests are integral for any political system. Protests are more likely to occur while a political system is undergoing the process of its development or transformation. Popular uprisings during the Arab Spring throughout the Middle East and North Africa that resulted in overthrowing of the political regimes in those countries appear to be the vivid

() Санкт-Петербургский государственный университет, 2019 
examples thereof $[1$, p. $340 ; 2$ p. $301 ; 3,54]$. Protests of that sort may have quite drastic consequences. In Syria, they evolved into a bloody armed conflict.

However, more established systems may be also prone to protests. The Western European governments are challenged by manifest frustration of the masses about the social and economic situations in those countries [4]. The current wave of the "gilets jaunes" (yellow vests) movement is spearing beyond the French borders, gaining momentum and acquiring a rather distinctive political character [5].

Thus, the probability of protests and their potential to cause drastic destabilization is the questions that shall not be overlooked. Kazakhstan is not immune from such developments; some mass protests accrued there as well. Understandably, these protests are generally seen as challenging the social stability. Given their acute importance, there have been increasing number of studies and surveys to measure the level of social tensions and conflict potential, conducted on the regular basis by several research institutes and think tanks in Kazakhstan [6, p. 90; 7, p. 56; 8, p. 51; 9, p.102; 10, p.175].

However, these days, we are not only witnessing the protests that are growing in terms of their frequency, intensity or composition of their participants, we are dealing with changing "discourses" and "repertoire" thereof. This actualizes and problematizes the question of how we study such protests. The enquiry that provided the basis for this article was conceived with this question in mind. Thus, the authors were well aware that, in addition to such a conventional method as survey, some newer, more adequate techniques of data collection to study protest behavior were to be employed. Those techniques included search query of the electronic and printed media; monitoring of the social media and social networks; and examining the content of the posts, i.e. complaints and queries, submitted electronically on the official websites of particular government agencies and officials. Those methods enabled the authors to have a clearer picture of the factors, root causes as well as of the protest behavior patterns in Kazakhstan.

Thus, the protests that have been occurring in Kazakhstan for the last decade are in the focus of the scholarly attention of the authors, who examined and analyzed the data collected by them independently and by other researchers in order to find the answer to the following questions: what issues are more likely to trigger protests in Kazakhstan; how can the protests, that already have occurred, be categorized in terms of their participants, subject matter, forms and means as well as the response of the authorities; how does the Internet influence the dynamics of the protests; what is the role of civil society; is there any probability of mass violet protests in Kazakhstan that could threaten political stability in this country?

As it has been mentioned above, the analysis is sourced by the primary and secondary data. The secondary data have been collected through a series of sociological surveys and studies conducted by the Institute of World Economy and Politics under the Foundation of the First President of Kazakhstan, the Institute of Eurasian Integration, the "Open Society" International Institute for Regional Research, the Kazakhstan Institute for SocioEconomic Information and Forecasting, the "Social Perspective" Public Foundation, the Research Institute for International and Regional Cooperation at the Kazakh-German University, the Kazakhstan Institute for Strategic Studies under the President of Kazakhstan, and the Kazakhstan International Bureau for Human Rights and Rule of Law.

As it will be shown further, the surveys informed merely on the issues that the respondents identified as the most possible triggers of future protests and on their own personal in- 
clinations to engage into such protest activities. The declaratory nature of such data prompted further attempts by the authors to find out more about how those declarations correlated with the actual protest behavior of the citizens of Kazakhstan. This is how the primary data was collected and analyzed via search query of the Kazakhstan press and the monitoring of the social media and social networks. Additionally, there was the five-year qualitative content analysis on the complaints and quires posted on the blogs of the governments agencies and officials and their respective Facebook accounts. Moreover, the study incorporated the transcripts of 35 in-depth interviews with the experts sampled according to their professional status and affiliation; civil servants, representatives of NGOs, think tanks, members of political parties, and security agencies officers.

\section{Potential Triggers of Protests in Kazakhstan}

Prior a more details analysis of potential triggers of the protest activity in Kazakhstan, the popular social feelings were examined in order to identify what people think about the likelihood of mass protests. According the sociological survey conducted in 2015, a third of respondents believed that there were good reasons for protesting and $27.6 \%$ of them said that the protests are "likely" to happen, while $6.8 \%$ were firmly convinced that protests might begin at any time soon. Importantly, the respondents with lower incomes were more likely to believe that there were all reasons for people to start protesting. The share of those who thought protests were "highly unlikely" or even "impossible" was $43.1 \%$ [9, p. 55].

Having studied people's expectations, the authors focused on those issues that might motivate people to participate into a protest. The social survey on the Standards of Living in Kazakhstan and Inequality gives the authors the grounds to argue that the social and economic issues: namely, unemployment, inflation, corruption, violation of the workers' rights, high housing and public utilities bills, and overall deterioration of the relations between the people and the state may become the most likely triggers for the protests in Kazakhstan (see Table 1).

The other argument is that the rise of the protest activity is never sudden, there are always some signs and indicators. The most important of such indicators are the lack of trust to the government and politicians, pessimistic attitudes to the future, uncertainty and lack of social security, various rumors, migration, complaints and resentment and so on. The authors had been examining the content of the complaints posted on the blogs of the government ministers and other officials as well as the social media posts for five years and found out that $80 \%$ of the complaints and posts examined were about unemployment, rising prices, and the lack of decent housing. People were also concerned about poor quality of medical services and corruption in the law enforcement. The analysis showed that economic inequality had caused resentment among general public and increased tensions between them and the state.

The authors' findings were reaffirmed by the experts interviewed during the study. "The root causes of conflicts are ignored or overlooked. Discontent and resentment is growing gradually approaching the critical level. Recent protests show that people are well aware of injustice. We live in a new social reality and the major feature thereof is profound dissatisfaction with the policies pursued by the political classes. Overwhelming majority of people are dissatisfied with their lives and craving for change" - said an interviewed expert. 
Table 1. Issues with Biggest Protest Potential and Possible Personal Involvement (\% of respondents)

\begin{tabular}{|l|c|c|}
\hline & $\begin{array}{c}\text { Factor that may trigger } \\
\text { protests }\end{array}$ & $\begin{array}{c}\text { Factors prompting personal } \\
\text { involvement in protests }\end{array}$ \\
\hline $\begin{array}{l}\text { Rising prices, rising utilities bills, } \\
\text { inflation, devaluation of the national } \\
\text { currency }\end{array}$ & 50,1 & 16,9 \\
\hline $\begin{array}{l}\text { Unemployment; law salaries and wages, } \\
\text { students' burses, pensions, and benefits }\end{array}$ & 50,5 & 18,8 \\
\hline Social inequality, income inequality, & 30 & 11 \\
\hline Lack of due process & 28,9 & 11,3 \\
\hline Lack of social justice & 27,9 & 10,8 \\
\hline $\begin{array}{l}\text { Violation of human rights, corruption, } \\
\text { abuse of power }\end{array}$ & 31 & 12,8 \\
\hline Problematic inter-ethnic relations & 17,9 & 6,9 \\
\hline Problematic religious issues & 19,9 & 6,3 \\
\hline $\begin{array}{l}\text { Actions and pronouncements of the } \\
\text { opposition }\end{array}$ & 14,3 & 4,9 \\
\hline $\begin{array}{l}\text { Problems of urbanization, migrants } \\
\text { (including those from rural areas) }\end{array}$ & 13,8 & 5,9 \\
\hline Environmental issues & 17,6 & 8,9 \\
\hline Inability to pay off the bank loans & 17,4 & 7,5 \\
\hline $\begin{array}{l}\text { No reasons to protest/to be involved } \\
\text { personally }\end{array}$ & 22,2 & 4,4 \\
\hline Other & & \\
\hline
\end{tabular}

Source: Standards of Living in Kazakhstan and Inequality, Social Survey, 2015 [9].

Therefore, it is very important to remember that failure to identify and understand the issues that are the most important for the majority of the peoples would rather mean that the root causes of protests remain overlooked and the factors of possible escalation of conflicts are not addressed properly. In the long run, such profound but rather latent discontent may have destructive social effect leading, potentially, to the spontaneous outburst of the masses.

Having processed the above data, the authors would rather suggest, in the most general terms, that the main cause of the protests in Kazakhstan is an apparent discrepancy between the declared goals of modernization and the methods how those goals are being fulfilled. It shall be noted that since its independence, Kazakhstan set a course of the reforms that should have been socially beneficial to the majority of its citizens. For example, the Addresses to the People of Kazakhstan of President Nazarbayev, if closely examined, offer a comprehensive but rather detailed program of social modernization [11, p. 92]. However, the authors concur with those experts who point at particular risks associated 
with poor implementation of such program by the public administration and formalist attitudes of the civil servants "on the gourd" together with corruption and embezzlement, all these compromise the entire development strategy in the eyes of the general public making it barely implementable [12, p. 50].

President Nazarbayev repeatedly stressed the necessity for the strategies and programs to be designed and adopted in a such way so that they would bring on improvements in healthcare, infrastructure and education. All necessary funds had been assigned, yet systematic work was never started. Real incomes have not been increasing. The share of food expenses of an average household in Kazakhstan is growing. Some vulnerable people have not been reached by the civil services responsible for providing targeted social care. The situation is even more aggravated as great number of government ministers and local akims (governors) fail to communicate with their constituencies, being unable or unwilling to listen to people and to convey the major points of the state policies [13].

\section{The Protests Occurred in Kazakhstan}

Having studied the issues that might motivate people to demonstrate their dissatisfaction, the authors focused on the protests that had occurred Kazakhstan during the last decade with the participants of various ages and walks of life: pensioners, students, workers, public sector employees and others.

The analysis of the press and electronic media materials as well as the social media content showed that those protests were sporadic in nature and limited in terms of their scope and subject matter. In other words, certain, not sizable groups of people protested about rather particular issues of their concerns, which, however, were not shared by broader public. For example, the heavy industry workers (more often employed at the enterprises partly or entirely owned by foreign owned) demanded the increases of the wages or elimination of the wage discrimination: the situation when the foreign employees are payed disproportionally higher than their local counterparts. Owners of the land plots protested against the demolition of houses and demanded the compensation of their losses. Pensioners protested against increasing utilities tariffs and bills. Women protested against raising the retirement age of female employees from 58 to 63. Their protests led to the resignation of the Minister of Labor and Social Security. Number of prominent public figures and activists expressed their concerns about the status of the official state language and about drastically deteriorating environmental situation in Kazakhstan. Students protested against raising of the tuition fees. Journalists agitated for better freedom of expression especially in the printed media and the Internet. Right-hand drive cars owners demanded the abolition of the restrictive measures imposed on them by the government. Hoodwinked investors demanded reparations and renationalization of all problematic construction industry enterprises. Interestingly enough, their protesters proved to be the most organized. For example, they formed the "Leave Houses to People" movement.

The Kazakhstan International Bureau for Human Rights and Rule of Law suggests that all the protest in Kazakhstan fall into one of the following three categories. The first includes the demonstrations and rallies of the people who are concerned about particular political issues. These, above all, are the actions aimed at demonstrating popular disagreement with the actions of the authorities (or the lack thereof), to manifest political disaffection, to convey the message of discontent and outrage to the government. The second in- 
cludes the protests related to all spectrum of social issues. The third category includes the actions triggered by difficulties faced by people due to the economic policies implemented in Kazakhstan such as labor disputes, mortgage and housing problems, utilities payments e.t.c. Importantly, the analysis of the character of all peaceful protests in Kazakhstan since 2010 shows the consistent trend of their depoliticization [15, p. 10], while social issues, have been gaining momentum (see Table 2).

Table 2. Intensity and Subject Matter of the Protests in Kazakhstan

\begin{tabular}{|c|c|c|c|}
\hline Year & Political & Economic & Social \\
\hline 2010 & $40 \%$ & $53 \%$ & $7 \%$ \\
\hline $2011-2012$ & $9 \%$ & $58 \%$ & $33 \%$ \\
\hline $2012-2013$ & $(1$ action $)$ & $70 \%$ & $29 \%$ \\
\hline 2014 & - & $49 \%$ & $51 \%$ \\
\hline 2015 & - & $45 \%$ & $55 \%$ \\
\hline 2016 & $15,5 \%$ & $15,5 \%$ & $69 \%$ \\
\hline 2017 & $5,5 \%$ & $16,6 \%$ & $78 \%$ \\
\hline
\end{tabular}

Source: The Kazakhstan International Bureau for Human Rights and Rule of Law, 2018 [15].

The fact that peaceful assemblies with political agendas are less common is attributed by the Kazakhstan International Bureau for Human Rights and Rule of Law to cleansing of the political space from any oppositional parties or public associations barely disloyal to the authorities. Secondly, under the law in Kazakhstan, there are very strict rules of holding peaceful assemblies. It creates serious thresholds for those who wishing to hold a protest actions and stipulates for severe sanctions for those who choose to disobey ${ }^{1}[14$, p.9].

The state control machinery and law enforcement is frequently used against those who are trying to organize peaceful assemblies with a political agenda. The Activists of the oppositional political forces are constantly under heavy pressure; permissions are denied on the regular basis, the leaders are detained - report the experts of the Kazakhstan International Bureau for Human Rights and Rule of Law, [14, p. 10].

The next important trend is a changing character of the protest behavior per se. This is largely due to the fact that modern protests technologies heavily depend on the use of the Internet. The Internet, according to researchers, is not only a mechanism for communication but a space where protest attitudes, beliefs and values are being developed and respective behavior patterns are being formed. Thus, regulation of the Internet, in some form or another, has been a constant item of the government agenda [15, p. 224].

Having examining the activities in the internet, the authors argue that one of its distinguishing features is that they may not even go beyond the cyber space. There have been numerous on-line petitions demanding demission of certain ministers or reformation in

${ }^{1}$ The Law of the Republic of Kazakhstan on Organization and Conducting of Peaceful Assemblies, Rallies, Processions, Pickets and Demonstrations in the Republic of Kazakhstan, available at: http://adilet. zan.kz/rus/docs/U950002126_ (accessed: 05.03.2019). 
certain spheres of public administration. It shall be noted that, in some cases, such forms of pressure prove to be rather effective. For example, the murder of Denis Ten, the famous figure skater, aroused indignation all over social networks; people demanded profound purge and reforms of the Internal Affairs Ministry. The other means to maintain pressure on the top officials personally or express profound disapproval of certain policies are the memes, GIFs, cartoons, and photographs ridiculing the respective personalities or actions with clear protest messages. These activities became increasingly popular and the authors categorize them as the form of protest behavior.

As for the efficiency of the Internet, some experts stress that on-line activities and activism may indeed impact political decision making. When the entire Cabinet in Kazakhstan was dismissed, the newly formed one lacked those ministers who were most strongly criticized in the social networks. When examining the findings of the survey conducted five years ago, the authors notice that $33.7 \%$ respondents who were regular internet users demonstrated their readiness to participate in mass protests more than others [10, p. 140]. With this in mind, one may reach the conclusion that on-line activism may pose threat. Under the condition where the government is either unwilling or unable to meet the social needs of population, on-line activism may be easily transformed into real off-line actions of such a scale that no one would be able to control.

There have been the protests in Kazakhstan that caused celebre throughout the country and prompted the authorities to intervene, namely the events in the city of Zhanaozen in $2011^{2}$ and the wave of the protests against the land reform in $2016^{3}$ [16, p.134]. In February 2019, mothers of many children protested vigorously all over Kazakhstan. The protests were triggered by the tragic death of five children in a fire in the city of Astana while both parents were absent from home trying to provide for their family. The mothers demanded to take urgent measures to solve housing problems, to provide law-income families with allowance so that they could purchase of thecoal in winter and pay their utility bills and to prolong the period when mothers are entitled for childcare benefits from one to three years [17].

It shall be noted that as the patterns of the protest behavior changed so did the responses of the authorities. Thus, during the latest protests of the mothers, the authorities demonstrated their readiness to find the solutions; the Ministry of Labor and Social Security publicly announced their commitment to tackle the issues raised during the rallies, the working group on larger families was established in Astana, local authorities provided some assistance. Various solutions were offered to the mothers by the regional akims (governors).

Although there have been instances when the internet protest activities and activism made the authorities to respond more or less promptly, a number of interviewed experts warned against premature conclusion that the Internet directly caused the recent resignation of the Cabinet in Kazakhstan. "It would be suffice to dismiss a couple of the most unpopular ministers to show that the authorities were responsive to the concerns of the

2 The strike of oil industry workers in the Mangystau Region of Southwest Kazakhstan resulted in major unrest in the city of Zhanaozen.

${ }^{3}$ In the spring of 2016, the amendments to land legislation caused negative reaction throughout in Kazakhstan. As a result, the public debate turned into the protests in a number of regions of Kazakhstan. To resolve the situation, the Land Reform Commission was established by the President Nazarbayev, which, eventually, provided the platform for a constructive dialogue between the state and the people. 
public. However, the fact the entire cabinet had to resign helped to diffuse the situation although the resignation per se was not caused by it" - one of the interviewed experts argued.

In the context of this study, it is also worth pointing out that the political classes, the Head of the State in particular, are apparently well aware of the importance of social issues. Speaking on February 27 before the delegates of the XVIII Congress of the "Nur Otan" party, Nursultan Nazarbayev once again emphasized that ensuring the decent standards of living and the overall progressive development of Kazakhstan should remain the priority. "The Government should pay special attention and take special care of the low income larger families" - said President Nazarbayev. Currently, more than 111 thousand families (571.6 thousand people) are the recipients of the targeted aid provided by the state [18].

The analysis of the protests in Kazakhstan shows that they may be rather efficient. Today, conventional wisdom suggests that some causation exists in this respect: "identification of a problem" followed by "protests" that lead to "awareness raising and public attention" and bring on the subsequent "change of the behavior of the authorities". Therefore, the authors alongside with some experts, stress the need for their better institutionalization: political protest behavior shall be better organized, self-regulated and institutionalized so that the norms and rules could be formulated and observed by the all parties concerned. Neither the state nor the public shall see protests as a provocation of the marginal, rather they shall be regarded as proper means to resolve the social conflicts. Thus, is important to be able to identify the moment when patience of people runs thin and the desperate masses are on the age of protests $[19, \mathrm{p} .7]$.

\section{Role of Civil Society}

The authors premise their analysis on the argument that a policy aiming at maintenance of social harmony is only effective if based on close engagement of the state and the civil society. Without underestimating the stabilizing role of the state, its institutions and organs in conflict resolution, it should be noted that when such a stability is achieved through a rigid vertical power its positive effect may not last. The well established channels of communication that provide for timely and clear feedback are necessary to prevent destructive conflicts, otherwise the system is just unsustainable in the long run.

So, when intervening in a conflict situation, the state often opts for using the police or security services. Although no one would argue against their involvement in a situation of acute clashes to prevent promptly any violent and other unlawful actions, one shall remember that such engagement deals only with the consequences while the root causes remain untackled and the latent conflict not revealed. Therefore, the autors would argue that the use of force, shall be considered as the last resort in avery particular circumstances due to the following reasons. Firstly, it may not resolve a conflict but push it underground. Secondly, it may provoke resistance instead of reaching an agreement. Thus, the use of force increases the likelihood of the conflict to reemerge. Finally, it may signal that the government lacks any constructive operational technologies of conflict management. In other words, the use of force most often makes it more difficult to achieve consensus, promotes destructiveness and makes conflicts more potent.

Among the institution of civil society, political parties are traditionally seen crucial in conflict resolution as they allow the different social strata and groups to reconcile their 
interests, At the same time, it should be noted that distrust of political parties has been an integral element of the political culture of Kazakhstan. People in Kazakhstan simply do not regard political parties as an efficient intermediary between the government and the citizens. The authors attribute such a distrust to rather apparent "imposter" character of those parties created "from above" and to the fact that the parties' infrastructure and membership are used to ensure electoral mobilization and voting turnout. The parties of the opposition are seen as ineffective.

Thus, in the authors opinion, political parties do not play any significant role in diffusing the tensions in Kazakhstan. Their own clashes rarely reflect the conflicts of interests of social groups notwithstanding the interests of those involved into the protest actions. They are often seen as nothing more than the clashes of personal ambitions. In other words, interparty interaction is an additional means of confrontation between various political forces failing to provide any institutionalized space for conflict resolution and maintenance of the balance of interests of various social groups.

NGOs, as another element of an institutionalized civil society, is traditionally seen as the important actor capable of sending to the authorities the signals that some preventive measures are urgently required in a particular domestic situation. In quantitative terms, the available data depicts quite confusing picture about the NGOs in Kazakhstan. Accursing to some estimates, there has been steady increase in the number of the non-governmental organizations: in 2006 there were more than 25,000 registered NGOs, whereas in 2011 their number exceeded 36,000. However, the revision conducted in 2016 revealed the reduction in the number of NGOs; as it turned out, some registered organizations had been inactive [20, pp. 54-55]. There are currently 2,931 organizations in the official NGO database by the Ministry of Religious Affairs and Civil Society of Kazakhstan [21].

In the course of our in-depth interviews, the experts suggested that the activity and agendas of Kazakhstan's NGOs focus more on the issues of private concerns of a limited number of people rather than on the common good. Too many of those organizations are the grantees of either international sponsors or the Government, too often their activities are sporadic, they operate when they have money and froze all activates when the granted funds are exhausted. Some NGOs are essentially fictitious. Some conduct the work that is of little resemblance of the statutory goals.

In this context, it is important to note that a number of studies revealed rather critical attitudes towards the non-governmental sector among general public in Kazakhstan. Together with political parties, they do not enjoy much trust: political parties (19.9\%), public associations (18.8\%), and the trade unions (17.8\%). Therefore, the overall reach of the NGOs sector in Kazakhstan remains insignificant [22, p. 137].

With that in mind, the authors argue that in order to improve the potential of the society to prevent mass destructive outbursts, the NGOs shall be engaged more into conflict situations, their preventive capacities shall be enhanced. For instance, the NGOs may participate in the development of the policies aimed at defusing of potential conflicts; protecting human rights; prompting the third sector activities beyond the major cities, reaching all the regions especially the remote rural areas; ensuring that their activities and initiatives are covered in the media on a regular basis.

The final premise of the analysis is that stability in a democratic nation is supposed to be based on social partnership. However, social partnership in Kazakhstan does not appear to be functioning effectively either. For example, the trade unions in Kazakhstan 
are not fully prepared to use all available methods to protect the interests and rights of the workers. They rarely initiate negotiations over collective agreements and barely monitor the observance of the agreed terms. Weakness and passivity of the trade unions inevitably leads to increased tensions between the capital and the labor. It is especially important as the employee-employer relations within Kazakhstan's industries are deteriorating, gradually becoming one of the most conflict-saturated spheres. Increasing number and scale of the strikes occurred throughout the country is the clear evidence of that [23].

\section{Probability of Mass Protests in Kazakhstan}

Having surveyed the triggers, scope, means, and participants of the protests in Kazakhstan, as well as the influence of the Internet, the role of the state and the civil society, the authors raise the question whether there is actual risk of emergent mass protests in Kazakhstan. The authors define mass protest as those meeting three following criteria: the first, they shall occur simultaneously in several locations, preferably those beyond the major cities; the second, the issue people are protesting about shall be of the broadest appeal possible, it shall concern the interests and the rights of the majority of people; the third, they shall involve people of all walks of life, those representing all (or almost all) classes and strata of the population. Thus, for the purposes of this study, mass protest are defined as a widespread public actions organized into a united movement to demonstrate resentment, objection, or disapproval of certain acute or intended actions of the authorities. Given the above definition, it can be argued that the events discussed above in this article do not meet the threshold.

Further, the authors argue that genuinely mass protests are rather unlikely in Kazakhstan in the near future as the citizens are not typically inclined to any sort of destructive behavior; their discontent is usually locally and topically limited. Our argument is premised on the following:

- Kazakhstan is still undergoing the process of societal structuration and stratification, the collective interests of various strata have not been fully grasped or articulated, the capacity of social groups for effective self-organization is still poor;

- there is no any organized political force, such as political parties, civic movements, or independent trade unions, that would be able and willing to transform protest sentiments into consolidated organized protest actions;

- the strategy of a consistent and rather large proportion of population is that of survival and adaptation.

In this sense, our suggestions are reaffirmed by the findings of the survey conducted to identify the level of resilience of the population in Kazakhstan that are quite illustrative: "it is not that bad after all" - $42 \%$ of respondents agreed with such statement; "life is hard, but still tolerable" — is the position of $28.2 \%$; "I may put up with such a life, but not for long" - said $23.5 \%$ of those being surveyed; and only $6.1 \%$ stated that they were not ready "to endure such a plight no longer" [24, p. 16].

- fear of change; even those who are strongly discontented about the current situation are not inclined to take any radical actions preferring graduate reforms to drastic changes, they would not alter their lifestyles or disturb their plans and aspirations however modest those might be. 
A number of studies surveyed in the context of this research reveal what people in Kazakhstan fear most and these are revolutions, mass rallies and demonstrations. The possible consequences of political protests are seen as negative rather than positive and are feared by majority of people [25, p. 176]. Therefore, the state is easily capable to neutralize those who participate in the protest actions. This capacity is only reinforced of overall uncertainty when their anxiety turns into fear of destabilization.

In the authors opinion, in the short term, these adaptation mechanisms may protect against social upheavals. But in the long term, such latent resentment, without any institutionalized forms to be demonstrated, may bring on outbursts of mass protest even riots with quite destructive consequences. Therefore, the authors would warn against the tendency to overestimate such resilience, since these forms of adaptation - being forced upon people - are rather unsustainable. Those whose interests have been systematically infringed sooner or later come to the idea that they would have to protect them by force. This is especially true of those who live below the poverty line, those who are deprived of any institutionalized and legitimate mechanisms to express their discontent. These people may become more susceptible to extremist forms of social and political behavior.

- absence of so-called "external actors" interested in meddling into Kazakhstan's affairs. Destabilization of Kazakhstan may result in destabilization of the entire region. Thus, the current situation makes both Russia and China economically dependent on maintenance of stability in Central Asia.

\section{Conclusions}

The authors reached the following conclusions. Firstly, there are consistently present factors in Kazakhstan that balance each other; those contributing into growth of the conflict potential and those defusing such potential. Secondly, the protests in Kazakhstan are most likely to be triggered by social and economic issues. Thirdly, protests in Kazakhstan shall not be seen as a mere indicator of instability, rather they are revealing the conditions when society is ready to adopt new legal and institutionalized means to express publicly the existing conflict of interests. Fourthly, as overwhelming majority of Kazakhstan's citizens are not inclined towards unconventional protest behavior or any unlawful means to resolve their problems, the probability of mass protests or conflicts in Kazakhstan remains rather low. Finally, conflict resolution mechanisms in Kazakhstan are poorly institutionalized as is evident in rather underdeveloped legal means and structures aimed at facilitating articulation of the grievances as well as reconciliation or balancing of the conflicting interests.

\section{References}

1. Lynch, M. (2014), The Arab uprisings explained. New contentious politics in the Middle East, Columbia University Press, New York, 352 p. sian)

2. Vasil'ev, A. and Petrov, N. (2012), Recipes of the Arab Spring, Algoritm Publ, Moscow, 345 p. (In Rus-

3. Brownlee, J., Masoud, T.E. and Reynolds, A. (2015), The Arab Spring: Pathways of repression and reform, Oxford University Press, Oxford, $346 \mathrm{p}$.

4. Quaranta, M., (2015), Political Protest in Western Europe Exploring the Role of Context in Political Action, Springer Publ., New York, 346 p.

5. Grossman, E., (2019), France's Yellow Vests - Symptom of a Chronic Disease, Political Insight, vol. 10, no. 1 , pp. 30-34.

6. KazISS (2014), Level of Social Conflict Potential (Social Survey Findings), Almaty. (In Russian) 
7. Zhusupova, A.S. (2014), Social Wellbeing in Kazakhstan-201", in Sotsial'nyi portret sovremennogo kazakhstanskogo obshchestva, Institut Aziatskih issledovanij Publ, Almaty, pp. 40-45. (In Russian)

8. Zhusupova, A. S. (2015), Pecularities of Social Wellbeing in Kazakhstan, in Social'nyj portret sovremennogo kazahstanskogo obshhestva, Institut Aziatskih issledovanij Publ, Almaty, 240 p. (In Russian)

9. Nurgalieva, M. (2015), Standards of Living in Kazakhstan and Inequality (Social Survey Findings), KISI pri Prezidente RK, Almaty. (In Russian)

10. Chernyh, I. (2014), Internet Communication in Kazakhstan: Level of Potential for Mobilization (Sociological Survey Findings), KISI pri Prezidente RK Publ, Almaty, 172 p. (In Russian)

11. Kartashov, K. (2018), Presidential Methods to the People of Kazakhstan; content analysis, Almaty. (In Russian)

12. Shibutov, M. (2017), Analysis of Social and Political Processes in Kazakhstan, in Babakumarov, E.(ed.), Sotsialnaia modernizatsiia Kazakhstana, Institut Evraziiskoi integratsii Publ., Astana, 368 p. (In Russian)

13. Nazarbaev, N. A. (2019), Cabinet of Ministers Must Resign, available at: //https://tengrinews.kz/kazakhstan_news/pravitelstvo-doljno-uyti-v-otstavku-nazarbaev-363761/ (accessed: 07.03.2019). (In Russian)

14. Duvanov, S. (2018), Right for Peaceful Assembly in Kazakhstan, Monitoring Report 2017, The Kazakhstan International Bureau for Human Rights and Rule of Law, Almaty. (In Russian)

15. Volodenkov, S. (2018), Internet Communication Technologies to Destabilize Political Regimes in Nation States, Problemy ustoichivosti politicheskikh sistem sovremennogo mira, International Conference, Moscow, pp. 221-233. (In Russian)

16. Almuhamedova, N.S., Karimova, M.S. and Zholdybalina, A. S. (2016), Public Debate on Land Reform: Chronology, Outcomes, Astana. (In Russian)

17. Mothers of Many Children Protest Throughout Kazakhstan, available at: https://eadaily.com/ru/ news/2019/02/19/po-kazahstanu-idet-volna-protestnyh-akciy-mnogodetnyh-materey (accessed: 03.03.2019). (In Russian)

18. President of Kazakhstan Addresses Delegates of XVIII Congress of the Nur Otan Party, available at http://www.akorda.kz (accessed: 03.03.2019). (In Russian)

19. Nikovskaya, L.I. (2012), Civil Society and Protests; What are the Implications?, Monitoring obshchestvennogo mneniia: ekonomicheskie i sotsialnye peremeny, no. 4 (110), pp. 5-13. (In Russian)

20. Rodionov, A. N. (2017), Studies and Expert Opinions on Perspectives of Civil Society, in Babakumarov, E (ed.), Sotsial'naia modernizatsiia Kazakhstana, Astana, pp. 50-59. (In Russian)

21. Ministry of Religious Affairs and Civil Society of Kazakhstan, NGOs database, available at: https:// infonpo.kz/ru/db_old_backup/ (accessed: 06.03.2019). (In Russian)

22. Baydarov, E. (2017), Analysis of Public Opinion on Current Issues of Foreign and Domestic Policies, in Babakumarov, E. (ed.) Kommunikativnaia politika respubliki Kazakhstan: sovremennoe sostoianie $i$ perspektivy razvitiia, Institut Evraziiskoi integratsii Publ., Astana, pp. 134-156. (In Russian)

23. Vakulchuk, R. and Overland, I. (2018). Kazakhstan: Civil society and natural resource policy in Kazakhsta", Public Brainpower, pp. 143-162. (In Russian)

24. Akhmetova, G. (2004), Typology of Social groups in accordance to their Adaptation Capacitie", Sajasat, no. 2, pp. 10-16. (In Russian)

25. Satpayev, D., Umbetalieva, T. and Chebotarev, A. (2013), Grey Zone or Challenges of the Times of Transformation, Al'ians Atlanticheskikh organizatsii Publ., Almaty, 48 p. (In Russian)

Received: November 17, 2018

Accepted: June 13, 2019

Author's information:

Gulnar O. Nasimova - Dr. Sci. in Political Science, Professor; gulnar.nasimova@kaznu.kz Marem M. Buzurtanova — PhD in Political Sciences; marem_buzurtanova@hotmail.com Nina A. Saitova - Associate Professor; nina.saitova@kaznu.kz 


\section{Социальные протесты в Казахстане: факторы и тренды}

\section{Г. О. Насимова, М. М. Бузуртанова, Н. А. Саитова}

Казахский национальный университет имени аль-Фараби, Республика Казахстан, 050040, Алматы, пр. аль-Фараби, 71

Для цитирования: Nasimova G. O., Buzurtanova M. M., Saitova N. A. Social protests in Kazakhstan: Factors and trends // Вестник Санкт-Петербургского университета. Философия и конфликтология. 2019. Т. 35. Вып. 3. С. 472-484. https://doi.org/10.21638/spbu17.2019.307

В статье исследованы особенности протестов в Казахстане, а также определены их основные факторы и причины. На основе анализа социологических исследований, жалоб граждан в правительство, мониторинга социальных сетей авторами обосновано, что протестный потенциал казахстанского общества связан прежде всего с социальными и экономическими проблемами. Кроме того, авторы акцентируют внимание читателя на том, что протестная активность вызвана противоречиями между целями политической и общественной модернизации Казахстана и методами ее осуществления. Представлена классификация социально-политических протестов в Казахстане, определена их масштабность. Раскрыты основные методы органов государственной власти, направленные на снижение социальной напряженности в казахстанском обществе. Исследована роль институтов гражданского общества в предотвращении конфликтов. Отмечено, что институты гражданского общества в Казахстане недостаточно способствуют предотвращению деструктивных конфликтов. Вместе с тем выявлены изменения не только протестного поведения казахстанских граждан, но и методов урегулирования конфликтов со стороны власти. Исследуется степень влияния Интернета на уровень протестности граждан. Результаты проведенных исследований позволяют авторам сделать вывод о том, что протесты в Казахстане имеют больше локальный характер и не оказывают разрушительного воздействия на общество. Опасность массовых акций, таких как социально-политические протесты, в настоящее время отсутствует. Это связано с осуществлением социально-экономических реформ, заинтересованностью граждан в укреплении политической стабильности, отсутствием организованной политической силы и институтов гражданского общества, способных консолидировать население к протестам, страхом казахстанцев перед негативными последствиями социально-политических протестов.

Ключевые слова: социально-политические протесты, конфликты, модернизация, государство, власть, гражданское общество.

Статья поступила в редакцию 17 ноября 2018 г.; рекомендована в печать 13 июня 2019 г.

Контактная информация:

Насимова Гульнар Орленбаевна - д-р полит. наук, проф.; gulnar.nasimova@kaznu.kz Бузуртанова Марем Магометовна - канд. полит. наук; marem_buzurtanova@hotmail.com Саитова Нина Алексеевна - доц.; nina.saitova@kaznu.kz 